\title{
Islamic State group grievance mobilization
}

\author{
Jared Edgerton ${ }^{*}$
}

1 Department of Political Science, The Ohio State University, Columbus, Ohio, USA

* E-mail: edgerton.37@osu.edu (JFE)

\begin{abstract}
Recent studies of terrorist and civil war combatant mobilization have yielded contradictory results, regarding whether combatants are motivated by economic incentives or group grievances. To understand this phenomenon, this paper uses novel data consisting of 4,101 individual foreign fighter data of Islamic State volunteers fighting in Iraq and Syria. Islamic State fighters are better educated and have similar rates of unemployment compared to males in their home countries. Further, Islamic State fighters also come from areas with better economic conditions and regions with politically marginalized and ethnically excluded groups. The effect of economic activity and group exclusion are statistically significant and positive across several sensitivity checks. These analyses suggest that Islamic State fighters are motivated by group grievances, in the form of relative ethnic group ranking, as opposed to economic incentives.
\end{abstract}




\section{Introduction}

Foreign combatants in extrastate conflicts pose a serious threat to noncombatants in both their home state and the country in which they are fighting $[1,2]$. In addition to providing military support, foreign combatants help terrorist and rebel organizations through access to financial resources, lobbying their home governments to enact favorable policies, and helping terrorist and rebel organizations use their respective states as safe havens [3, 4]. In turn, terrorist and rebel organizations with external support are especially resilient in the face of military intervention, which poses a significant problem for states combating transnational terrorist and rebel organizations, such as al Qaeda, Colombian paramilitaries, and the Islamic State [5].

Despite increasing recognition in national security and policy circles that foreign combatants pose a threat, we know surprisingly little about why people join modern insurgent groups. Extant studies of foreign combatant mobilization primarily rely on qualitative interview data or aggregate the count of combatants to the state level. Although both approaches offer insights into motivation of combatants, these approaches introduce potential biases. If researchers use state level variables to predict the count of combatants, they may miss crucial subnational dynamics which are actually driving mobilization. For example, the Islamic State draws recruits heavily from the Caucasus region of Russia, but fewer combatants from other populated cities in the country (see Fig 1). Within Russia, the Caucasus region has idiosyncratic cultural and historical characteristics compared to other parts of the country. If a researcher uses the count of volunteers from Russia as a unit of analysis, they may miss the important local dynamics which are actually causing foreign fighter mobilization.

To shed light on the question of the motivations of foreign fighters, this paper leverages a unique dataset of Islamic State job applications that were leaked to Western news media and intelligence agencies by a former Islamic State soldier [6]. The leaked documents included over four thousand job applications of mostly foreign fighters who had traveled to Syria to join the Islamic State between 2010 and 2015. These documents include the fight- 


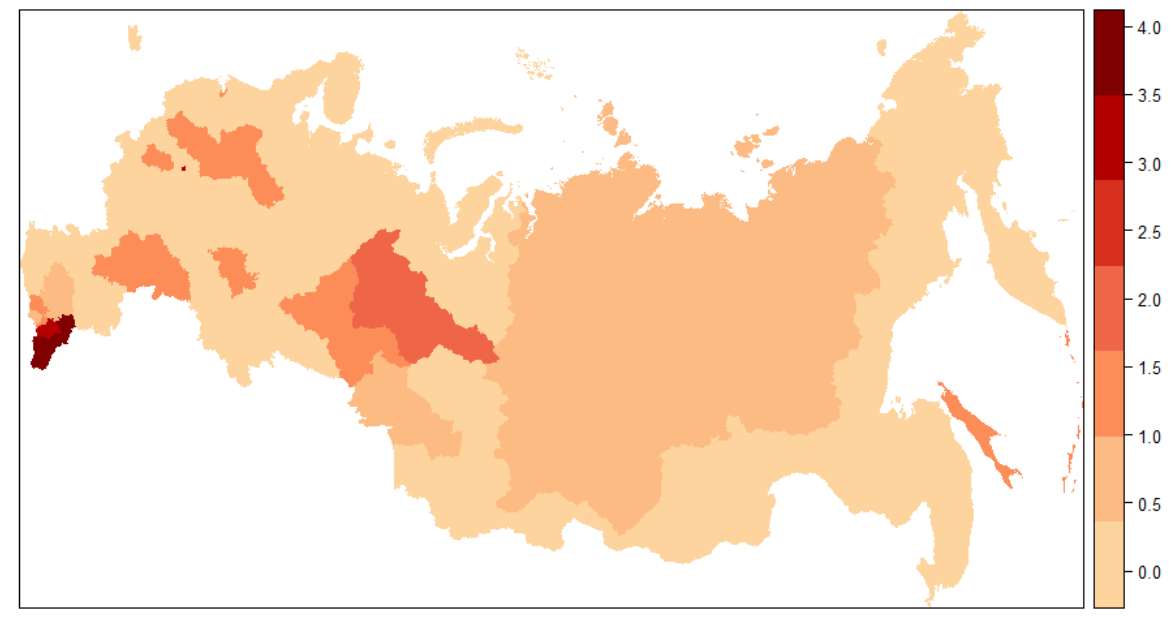

Figure 1: Heat map of the log count number of Islamic State volunteers from Russia. Most volunteers within Russia are from the Northern Caucasus; particularly North Ossetia-Alania, Ingushetia, Chechnya, and the Republic of Dagestan. Within Russia, these regions have faced higher rates of violence and poverty, compared to the median region. Further, these regions are also culturally distinct from other parts of Russia, with a majority of citizens identifying as Sunni Muslim.

ers' home states and cities, date of birth, educational attainment, and previous occupation before joining the Islamic State [7]. A journalist who writes on the Islamic State provided us with the documents for analysis. Crucially, the journalist was able to verify the authenticity of the documents by calling the relatives of the volunteers. Several researchers have also used a similar corpus of Islamic State documents for their research [8, 9]. Further, several organizations, including the United States Military Academy West Point, have published descriptive reports with the data $[10,11]$.

The data presented in this paper is distinct from the first treatment of the documents in two ways. First, the data is aggregated to the 0.5 geospatial subnational units (approximately 50 by 50 kilometer regions), instead of aggregating to the state level. Using the 0.5 geospatial unit as our observational unit helps us gain deeper insights into the micro-processes that drive mobilization. And second, this paper presents an individual level analysis for the fighters against the populations of their home states [9].

The Islamic State offers a compelling case study for understanding the motivations of 


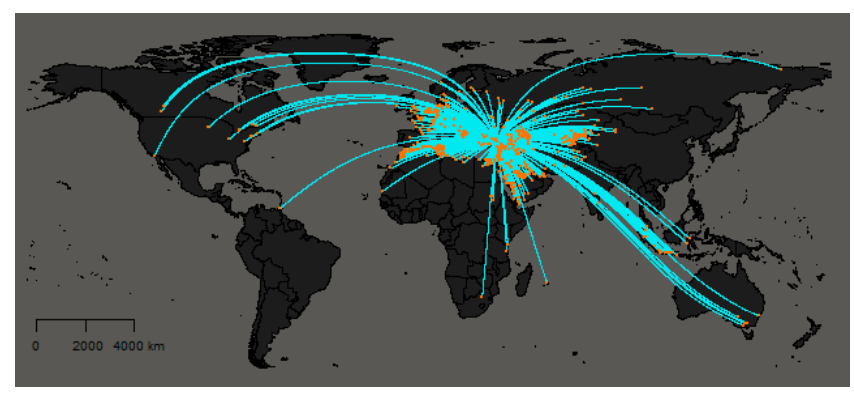

Figure 2: Network of Islamic State fighters and their home countries. The orange points are proportional to the log of the number of volunteers from a respective home city. The Islamic State foreign fighters are predominantly from the Gulf States, North Africa, Turkey and Russia; however, there are also foreign fighters from the United States, Canada, Germany, France, and the United Kingdom.

foreign combatants for two reasons. First, the Islamic State has been incredibly successful in recruiting foreign fighters. Between 2010 and 2015, the Islamic State drew recruits from over 60 countries; including China, France, Russia, Saudi Arabia, and the United States (see Fig 2). Second, the Islamic State poses a significantly larger threat to civilians than other terrorist and rebel organizations. During that time period, the Islamic State carried out almost 3,500 attacks, totaling 22,462 fatalities, making it the deadliest terrorist and rebel organization over the last five years [12].

Central to our argument is that foreign combatants are motivated by group marginalization and exclusion. Specifically, Islamic State foreign fighters are mobilized by changes in the relative importance and social rank of their in-group versus an out-group, as opposed to economic incentives (i.e. grievance versus greed). Researchers in the economic greed camp argue that combatants lack economic opportunities (i.e. have lower levels of education and higher rates of unemployment). Combatants therefore participate in civil war and terrorism to better their economic situation $[13,14,15,16,9]$. Researchers in the group grievance camp argue that combatants are motivated by group identity issues - including the religion, ethnicity, and political affiliation of combatants - rather than economic conditions [17, 18]. Under this theoretical framework, an individual's self-worth is influenced by a comparison of their in-group to other out-groups; particularly, if their in-group is subjugated by other 
out-groups, shares power within a coalition, or dominates the society. In the case of the Islamic State, the cleavages in group rank are between Sunni and Shi'a Muslims. In several states dominated by Sunni leaders, Shi'a Muslims are subjugated by Sunni leaders and vice versa. Changes in the rank status of groups can lead to conflict [19]. Consistent with this theory, researchers have found that combatants motivated by group grievances have higher rates of education because they are motivated by political and cultural issues, which requires an understanding of larger social dynamics within a state or the world [20, 21, 22].

We use two analytic approaches to assess the claim that foreign combatants are mobilized by group grievances. First, we compare the level of education and rate of unemployment for Islamic State fighters compared to the male populations of their home countries. Second, we aggregate count data for the Islamic State fighters to 0.5 geospatial regions and test the effect of group marginalization and nighttime lights (i.e. economic activity) on mobilization. If Islamic State fighters are mobilized by group grievances we expect for them to have higher levels of education and to come from regions with politically marginalized or excluded groups $[23,24,19]$. Conversely, we expect for Islamic State fighters to have similar rates of unemployment and the effect of nighttime lights on the rate of volunteers from a geospatial region to be null.

We find strong evidence that Islamic State soldiers are driven by ideational rather than material motives. These results are distinct from several recent studies. First, we find strong evidence that Islamic State foreign fighters are motivated by group grievances, as opposed to macro-statewide economic conditions. Second, we find that at an individual level, Islamic State fighters have a similar, or lower, rates of unemployment than males in their home countries conditioned on age. Further, at a subnational level, Islamic State fighters come from regions with higher levels of nighttime lights (i.e. greater economic activity). The remainder of the paper is divided into the following sections: (i) theory and mechanism, (ii) materials and methods, (iii) results, (iv) sensitivity analysis, (v) discussion, and (vi) conclusion. 


\section{Theory and mechanism}

\section{Theory}

In ethnically hierarchical states, changes in political and social power of subordinate groups can precipitate inter-group violence. Between group cleavages are especially pronounced in states which have centralized political power for specific ethnic groups, such as Iraq, Syria, Russia, and China [19]. Within the aforementioned states, various ethnic groups are prevented from accessing political and social power and tend to be more impoverished than other groups within the society $[25,26,27,28]$. In the case of the Syrian Civil War, the rival rebel, government, and insurgent group can be understood as extensions of in- and out-group cleavages, particularly religious divisions between Shi'a and Sunni Muslims.

Over the course of the Islamic State's military campaigns, they have drawn fighters from over 60 states, including Chechen, Turkmen, and Uyghur recruits. These recruits are notable because they associated with oppressed Sunni Muslim populations within their states. Conversely, anti-Islamic State military forces primarily draw recruits from Shi'a Muslim populations; particularly Iranian volunteers. After the Islamic State captured several regions of Iraq, Iran intervened on behalf of the Iraqi government using the People's Mobilization Committee (PMC) as a proxy organization to fight in Iraq and Syria. The PMC is an umbrella organization composed of over 60 Shi'a groups, with three distinct factions: (i) groups loyal to Ayatollah Ali Khamenei, Iran's supreme leader; (ii) groups loyal to Muqtada al-Sadr, an Iraqi Shi'a religious leader; and (iii) groups loyal to Grand Ayatollah Ali al-Sistani, an Iraqi Shi'a religious scholar [29]. Both the Sunni combatants for the Islamic State and Shi'a combatants for the PMC are mobilized by regional changes in their respective in-group rankings; particularly, recent gains in political power by Shi'a Muslims within the Iraqi government and Sunni Muslims in several north African states [19].

In addition to the recruitment populations, several political and religious leaders have framed the Syrian Civil War as competition between Sunni and Shi'a Muslims. Most notably, 
Egyptian Cleric Qaradawi called on all able bodied Sunni Muslims to join the Islamic State's military campaign in Syria [30]. In addition to Qaradawi's comments, political leaders have also warned that conflicts in the Middle East could produce asymmetric political power between Sunni and Shi'a states. In 2005, Jordanian King Abdullah II bin Al Hussein warned the Iraq War may produce an Iran-Iraq alliance which would shift the balance toward Shi'a states in the Middle East [31]. These religious appeals are consistent with a group ranking based understanding of ethnic violence [19].

The Islamic State also directly invokes out-group animus to generate support for the war and mobilize new fighters. In a May 2015 issue of the Islamic State propaganda magazine, Dabiq, they describe the military campaign as a fight between Sunni and Shi'a regional interests.

The West and its allies have, once again, been caught completely by surprise as they now find themselves fighting not just one enemy in Iraq and Sham, but now an international army of mujahidin numbering hundreds of thousands in different countries, whole continents apart. It's taken the coalition the best part of a year to put together a campaign against the Islamic State that is only now seeing a Shi'a mob supported by coalition aircraft make moves against Tikrit, but that's old news before it's even begun. Why focus on Tikrit when the Middle East, Africa, and Asia are now on fire [32]?

Across 28 issues of the Islamic State's propaganda magazines, approximately 10 percent of all the content was related to religion. Conversely, the magazine rarely discussed economic issues, with less than 1 percent of magazine content about poverty, money, income, or government wealth (see Fig 3 for the word counts in the magazine). This is particularly notable because between 2014 to 2015 the Islamic State was generating $\$ 81$ million in monthly revenue through natural resource wealth and taxes [33]. 


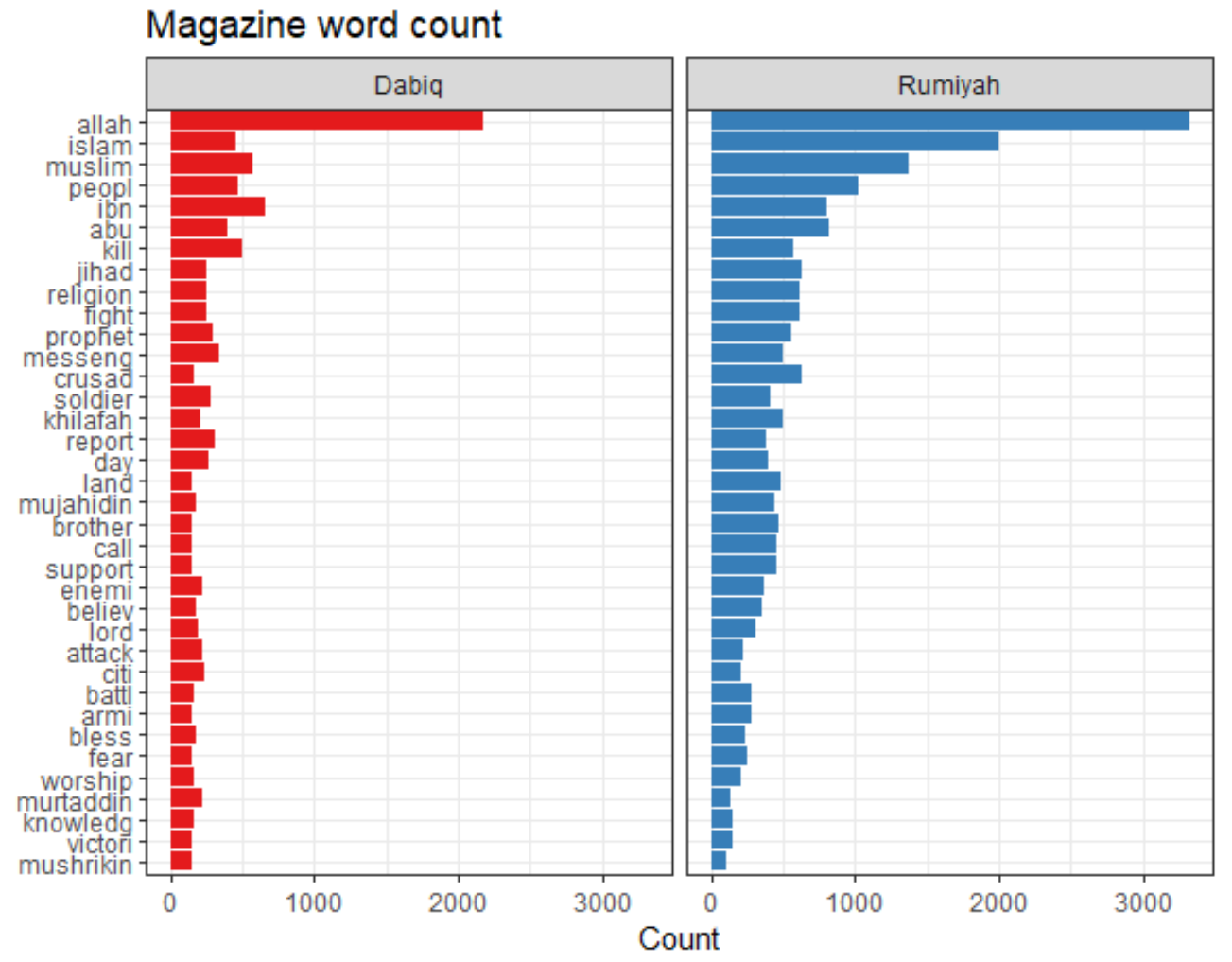

Figure 3: The most frequently used words in Dabiq and Rumiyah Islamic State magazines. 


\section{Mechanism}

To test the relationship between group ranking (e.g. group grievances) on mobilization we analyze both individual and environmental causes for mobilization. For the individual analysis, we compare the mean years of education for Islamic State fighters against the male populations of their home countries using one-sample $t$-tests. Better educated individuals are more aware of regional and global events which affect their relative group ranking. Further, the opportunity cost of joining a rebel movement is higher for educated individuals because it is easier for them to find different or more lucrative employment. Thus, if Islamic State combatants are motivated by group grievances, we would expect for fighters to be better educated compared to males in their home country.

Our primary mechanism for mobilization at the 0.5 geospatial level is the group exclusion variable. The group exclusion variable indicates if there is an ethnic group within a geospatial area blocked from political power, or discriminated against by dominant ethnic groups within the region between 2009 to 2013. The group exclusion mechanism is a close approximation of group ranking grievances because it captures in- and out-group tension.

In addition to the group grievance analyses, we also test the effect of economic incentives on mobilization. First, we compare the unemployment rate of Islamic State combatants against the proportion of males unemployed in their home states using one-sample $z$-tests. If Islamic State combatants are mobilized because of high unemployment (as previous re-

search has suggested), we would expect for the Islamic State fighters to have higher rates of unemployment than males in their home country [9]. Second, we test the effect of nighttime lights and the national unemployment rate on Islamic State combatant mobilization at the 0.5 geospatial level. The use of nighttime light data as a measure for economic activity is well established in existing literature, with higher levels of nighttime lights associated with greater economic activity $[34,35,36]$. Thus, if Islamic State recruits are mobilized by economic incentives, we would expect for higher levels of nighttime lights to reduce the rate of volunteers, while, higher rates of unemployment to increase mobilization at the subnational 
level.

\section{Materials and methods}

The data was provided to the research team by a journalist who writes on the Islamic State. Before the analysis, the research team worked with their university institutional review board to address issues related to the combatants' privacy. To help ensure the protection and privacy of the combatants' information, the applications were anonymized with each combatant given a code number instead of their name and all team members completing appropriate ethics training to work on the project. A team of Arabic coders translated and coded the Islamic State job application data, with each team member validating a subset of the other translators' work. For the analysis, we are primarily interested in the level of education, previous occupation, home city and state, and date of birth entries listed in the Islamic State job applications. Of the 4,101 applications, 21 percent of applications are missing the educational attainment, 11 percent of applications are missing the previous occupation, 8 percent of applications are missing the home cities of the foreign fighters, and 2 percent of applications are missing the date of birth. Fig 4 displays the count of volunteers by previous occupation and education by region.

\section{Education}

The open response entries on the Islamic State job application for level of education were recoded to: (i) middle school or less, (ii) some high school, (iii) high school degree, (iv) some college, (v) college degree of greater, and (vi) vocational and religious training. To estimate the mean years of education for Islamic State foreign fighters, we coded middle school or less as 8 years of education, some high school as 10 years of education, high school as 12 years of education, some college as 14 years of education, college degree of greater as 16 years of education, and vocational and religious training as 12 years of education. We then performed 


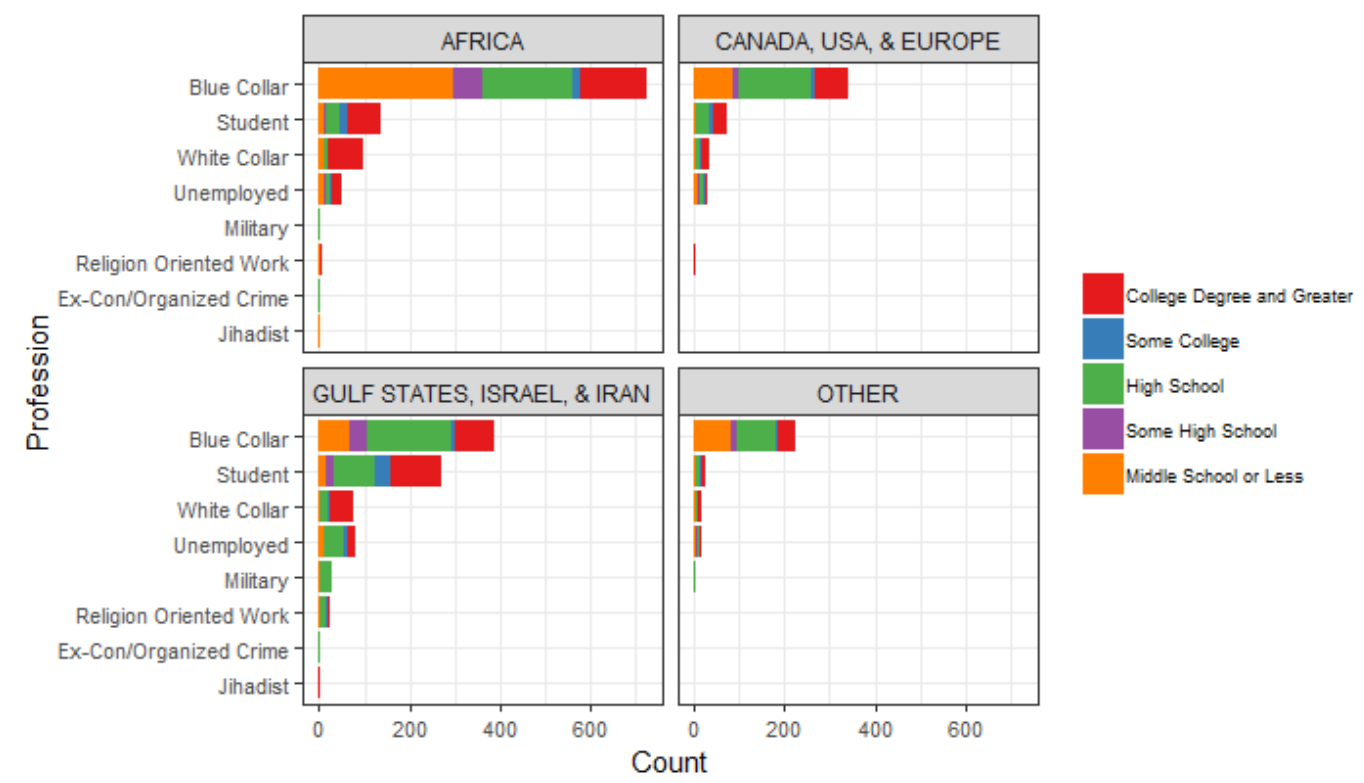

Figure 4: Counts of previous occupations and education levels of Islamic State combatants by region. In total, 65 percent of volunteers had a blue collar occupation, 18 percent were students, 8 percent had a white collar occupation, and 7 percent were unemployed before joining the Islamic State.

one-sample $t$-tests for each country where there are 20 or more Islamic State foreign fighters against the Human Development Index estimates for mean years of education for males per country averaged over 2010 to 2012 [37]. Our hypothesis follows:

$$
\begin{aligned}
& H_{0}: \bar{x}_{i}=\mu_{i} \\
& H_{1}: \bar{x}_{i} \neq \mu_{i}
\end{aligned}
$$

where $\mu_{i}$ is the mean years of education for males by country and $\bar{x}_{i}$ is the mean years of education for Islamic State fighters by country. In total, there are 24 states with over 20 volunteers. To adjust for multiple comparisons, we use a Bonferroni correction so the experimentwise error rate is 0.05 . 


\section{Unemployment}

The open response entries on the Islamic State job application for previous employment were recoded to: (i) student, (ii) blue collar occupation, (iii) white collar occupation, (iv) Jihadist, (v) previously incarcerated or black market profession, (vi) military, (vii) religionoriented work, and (viii) unemployed. The proportion of unemployed Islamic State fighters was determined by adding the number of volunteers who identified as Jihadist, previously incarcerated or black market profession, and unemployed divided by all volunteers minus the students. To evaluate the difference in proportion unemployed, we use one-sample $z$ tests for the proportion of unemployed Islamic State combatants against the proportion of unemployed males in their home country for all states which had 20 or more volunteers [38]. Our hypothesis follows:

$$
\begin{aligned}
& H_{0}: \bar{p}_{i}=\pi_{i} \\
& H_{1}: \bar{p}_{i} \neq \pi_{i}
\end{aligned}
$$

where $\pi_{i}$ is the proportion of unemployed males by country and $p_{i}$ is the proportion of unemployed Islamic State combatants by state. We use a Bonferroni correction to adjust for multiple comparisons so the experimentwise error rate is 0.05 .

\section{Group exclusion}

For the subnational analysis, the home cities of Islamic State volunteers were aggregated to the 0.5 geospatial region (approximately 50 by 50 kilometers). All geospatial regions within a country are included in the analysis if there was at least one volunteer from the country. In total, 46,805 geospatial regions are included from 64 countries. Only 2 percent of the geospatial regions within the data have one or more fighters during the time period. Further, the count of Islamic State combatants from a region is highly overdispersed (see Fig 
5). We address the overdispersed count outcome in two ways. First, we use a zero-inflated negative binomial model (ZINB). The ZINB model is useful because it models both the count process and zero stage of the data generating process. Namely, our data has both structural and sampling zeros. For example, there are several culturally distinct and underpopulated regions, such as rural regions of North Dakota in United States, within the data. These underpopulated and culturally distinct regions are structural zeroes in that they will only produce zeros in the model. Conversely, there are regions within the data that experience sampling zeros in the count stage of model. These regions could have produced Islamic State foreign fighters but have a zero outcome. In the first stage of our model, we predict which regions produce Islamic State recruits. In the second stage of the model, we measure what increases the rate of Islamic State recruits within the region. The model follows:

$$
P\left(y_{i}=j\right) \begin{cases}\pi_{i}+\left(1-\pi_{j}\right) g\left(y_{i}=0\right), & \text { if } j=0 \\ \left(1-\pi_{i}\right) g\left(y_{i}\right), & \text { if } j>0\end{cases}
$$

with $\pi_{i}$ representing a logistic function and $g\left(y_{i}\right)$ representing the negative binomial distribution. Second, for our main model we bootstrap the outcome. This helps address statistical inference issues related to outlier counts in the observed data.

To better estimate the treatment effect of group exclusion on mobilization, in the first model we control for the log of population and nighttime lights in the first (i.e. logistic model) and second (negative binominal) stages of the model. We also include country fixed effects in the second stage of the model. In the second model, we use the same control variables and mechanism, but cluster the data by geospatial site in the second stage of the model. In the last model, we use the unemployment rate of males in the first stage of the model instead of nighttime lights as a measure for economic activity within a geospatial region. 


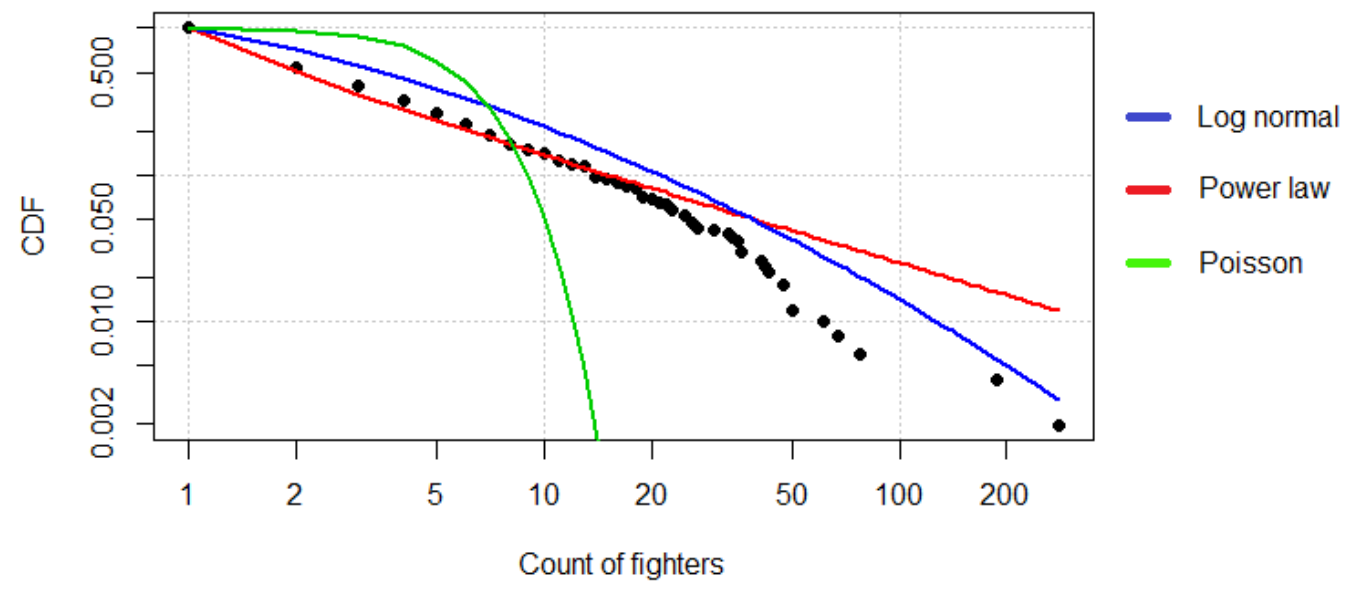

Figure 5: Cumulative distributions for the count of Islamic State recruits by geospatial region. The count of fighters is highly overdispersed, but not scale free.

\section{Results}

\section{Education}

Fig 6a displays the confidence intervals for the difference in mean years of education adjusted for multiple comparisons. Islamic State foreign fighters from 18 out of the 24 countries in the analysis have higher mean years of education than the male population of their home countries. This is consistent with a group ranking understanding of combatant mobilization.

\section{Unemployment}

Figure $6 \mathrm{~b}$ displays the confidence intervals for the differences in proportion unemployed for Islamic State fighters compared to males in their home countries. Foreign fighters from 8 out of 23 countries have lower proportions of unemployment, with 14 out of the 15 remaining states having a confidence interval which overlaps zero. For each country comparison the probability of a type one error is approximately 0.002 . Thus, the probability that we would randomly observe that Islamic State recruits from eight states having a lower proportion of unemployment compared to their home countries is $>0.001$. This suggests that overall, Islamic State foreign fighters had lower rates of unemployment before joining the Islamic 


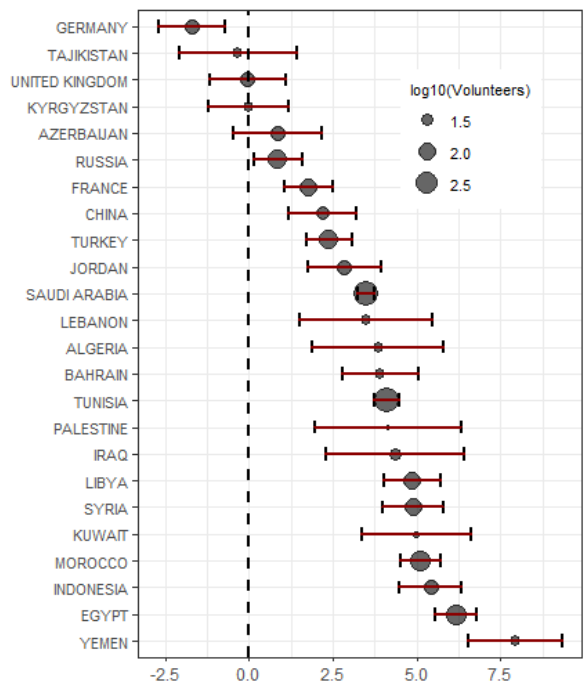

(a) Mean years of education.

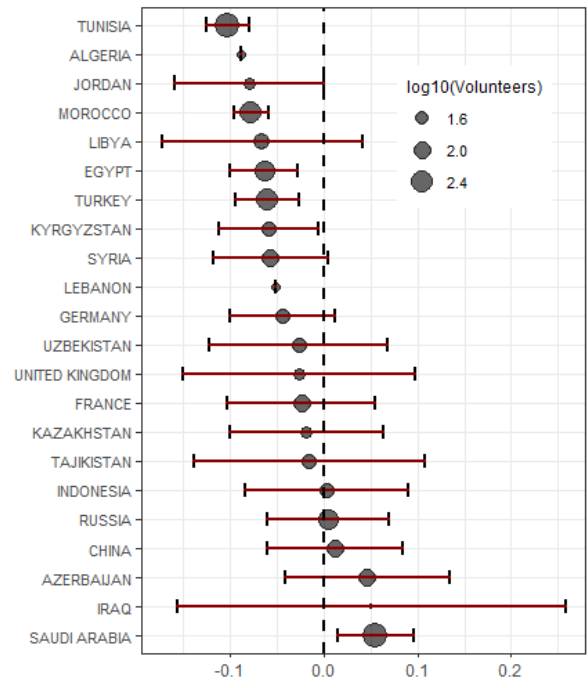

(b) Proportion unemployed.

Figure 6: The $t$-test confidence intervals for difference in mean years and $z$-test confidence intervals for difference in proportion unemployed. The mean years of education for Islamic State fighters is compared to the Human Development Index estimations for mean years of education for males in their home countries. The proportion of unemployed Islamic State fighters is compared to World Bank estimates for unemployed males in a country. The experiment is adjusted for multiple comparisons so both experiments have a 0.05 error rate.

State compared to males in their home countries.

\section{Group exclusion}

Table 1 displays the ZINB regression on the count of Islamic State recruits from a geospatial region. Notably, across all three models we find evidence that Islamic State combatants are mobilized by group ranking grievances, compared to material incentives. In all models, the group exclusion mechanism is statistically significant and positive. Further, all bootstrap estimates for the group exclusion variable in the first model are positive, with group exclusion increasing the count rate of Islamic State recruits by an estimated 6.90 times (see Fig 7a). This suggests that group ranking grievances increases the count of Islamic State recruits from a geospatial region.

Fig $7 \mathrm{~b}$ displays the nighttime lights estimates for the first and second stage of the 
Table 1: Bootstrapped and MLE estimates for the effect of group exclusion on mobilization. Group exclusion and nighttime lights are statistically significant and positive in the count stages of all three models.

\begin{tabular}{|c|c|c|c|}
\hline \multirow[b]{2}{*}{ Second stage } & \multicolumn{3}{|c|}{ Count of Islamic State combatants } \\
\hline & $\begin{array}{c}\text { Bootstrap estimates } \\
\text { ZINB }\end{array}$ & $\begin{array}{c}\text { Maximum likelihood } \\
\text { ZINB }\end{array}$ & $\begin{array}{c}\text { Maximum likelihood } \\
\text { ZINB }\end{array}$ \\
\hline Group exclusion & $\begin{array}{c}1.932 \\
(0.364)\end{array}$ & $\begin{array}{c}1.975 \\
(0.180)\end{array}$ & $\begin{array}{c}0.598 \\
(0.169)\end{array}$ \\
\hline Nighttime lights & $\begin{array}{c}0.448 \\
(0.065)\end{array}$ & $\begin{array}{c}0.440 \\
(0.050)\end{array}$ & $\begin{array}{c}0.460 \\
(0.056)\end{array}$ \\
\hline $\log$ (population) & $\begin{array}{c}1.371 \\
(0.472)\end{array}$ & $\begin{array}{l}1.359 \\
(0.254)\end{array}$ & $\begin{array}{c}1.693 \\
(0.284)\end{array}$ \\
\hline Constant & $\begin{array}{l}-5.156 \\
(3.479)\end{array}$ & $\begin{array}{l}-4.382 \\
(0.980)\end{array}$ & $\begin{array}{c}6.897 \\
(0.714)\end{array}$ \\
\hline Country fixed effects & $\mathrm{Y}$ & Y & $\mathrm{Y}$ \\
\hline cluster(gid) & & Y & $\mathrm{Y}$ \\
\hline
\end{tabular}

First stage

\begin{tabular}{lccc} 
Nighttime lights & $\mathbf{- 5 . 6 6 3}$ & $\mathbf{- 5 . 6 8 0}$ & \\
& $\mathbf{( 1 . 4 3 5 )}$ & $\mathbf{( 0 . 5 9 7 )}$ & \\
$\log ($ population) & -0.888 & $\mathbf{- 0 . 8 5 4}$ & $\mathbf{- 3 . 2 4 8}$ \\
& $(0.554)$ & $\mathbf{( 0 . 3 6 1 )}$ & $\mathbf{( 0 . 2 8 0 )}$ \\
& & & -0.143 \\
Unemployment rate & & $(0.077)$ \\
& & & $\mathbf{3 . 9 1 5}$ \\
Constant & $\mathbf{- . 7 7 4}$ & $\mathbf{- 1 . 7 6 3}$ & $\mathbf{0 . 3 2 0}$ \\
& $\mathbf{( 0 . 7 7 5 )}$ & $\mathbf{( 0 . 4 0 5 )}$ & 42,436 \\
\hline Observations & 46,805 & 46,805 & 5.467 \\
RMSE & 3.953 & 2.698 & \\
Simulations & 2,500 & & \\
\hline
\end{tabular}

Note: Bolded values are statistically significant at 0.05 level and standard errors are in parentheses. 


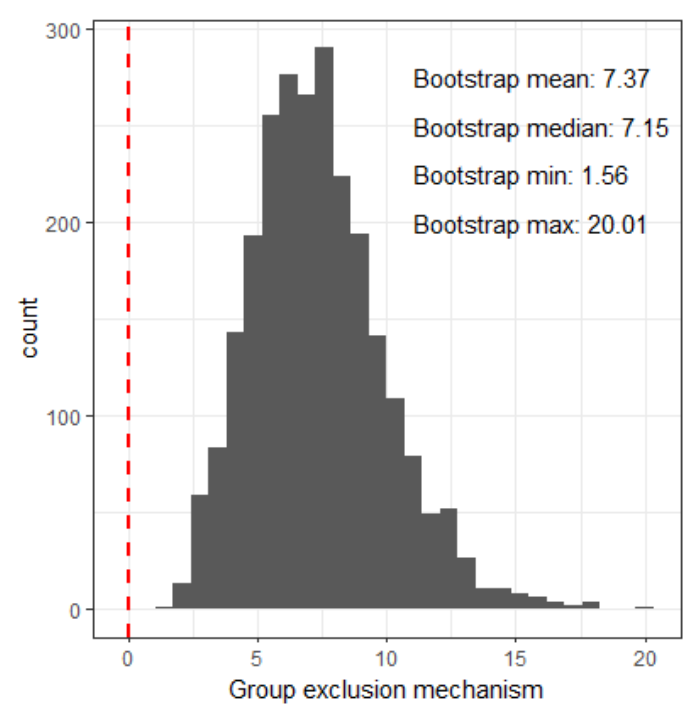

(a) Bootstrap mechanism estimates

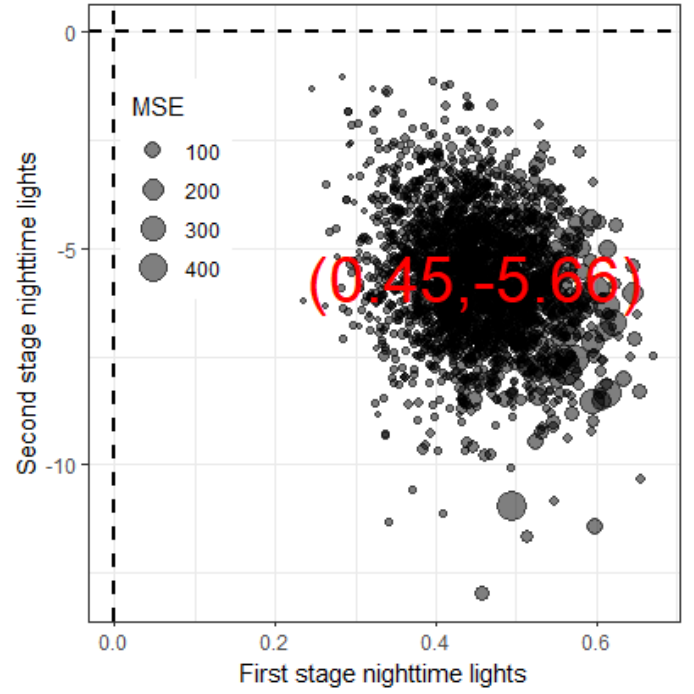

(b) Bootstrap control estimates

Figure 7: Bootstrap coefficient estimates for the group exclusion mechanism and nighttime lights. All second stage estimates for group exclusion and nighttime lights are statistically significant and positive. This suggests that the presence of excluded group and greater economic activity increases the rate of Islamic State fighters from a region. Likewise, the first stage estimates of nighttime lights suggest that areas with higher economic activity are more likely to produce fighters.

bootstrapped ZINB model. In the second stage of the model, nighttime lights is statistically significant and positive, while statistically significant and negative in the first stage of the model. This suggests that increases in the level of nighttime lights increases the count rate of Islamic State recruits from a geospatial region by 1.565 times and makes it more likely that a spatial region will produce recruits by 0.003 . This finding is supported by the first stage estimate of nighttime lights in the second and third model, and the second stage estimate of nighttime lights in the second model [39]. Last, in the third model, we find that in the first stage of the model, the effect of the unemployment rate of males within a country is negative, but not statistically significant at the 0.05 level [40]. Thus, higher rates of unemployment have an indeterminate effect on Islamic State combatant mobilization.

In total, these findings support a group grievance based understanding of combatant mobilization. Specifically, in the first and second model the effect size of group exclusion on the rate of combatant mobilization is larger than both nighttime lights and the log of 
population. Moreover, better economic conditions appear to increase the rate of volunteers from a region, while the effect of higher unemployment in the first stage of the model is null. These findings are supported by the individual level education and unemployment tests, which found that combatants were better educated and had lower, or similar, rates of unemployment to males from their home countries before joining the Islamic State.

\section{Sensitivity Analysis}

To validate the model results, we performed a series of sensitivity analyses, including: (i) $t$-tests on the mean years of education conditioned on age, (ii) $z$-test on the proportion of unemployed Islamic State fighters conditioned on age, and (iii) conduct difference in mean and mean rank tests on the count of Islamic State recruits on matched geospatial data [41, 38]. For the mean years of education sensitivity analyses, we subset the Islamic State combatants by those who are 15 and 25 years older. We then conduct one-sample $t$-tests for the combatant mean years of education against males from their home countries in those age ranges for every state that had at least 20 recruits. For the unemployment proportion sensitivity analysis, we subset the number of Islamic State combatants to volunteers between the ages of 15 and 25 and then compare the proportion of unemployed fighters to the proportion of unemployed males in their home countries in the same age range for every state with 20 or more volunteers. Last, we match the geospatial data on the group exclusion mechanism using the polity of the state, rate of unemployed males, political stability, religious cleavages within the state, nighttime lights, the log of population, number of terrorist fighters from the region, and country fixed effects $[42,40,43,39,12]$. We then run a $t$-test and a Wilcoxon rank sum test to evaluate difference in the count of Islamic State recruits from regions with and without excluded groups. The Wilcoxon rank test is a non-parametric test for differences between groups, which helps address potential issues with non-normal data generating processes. 


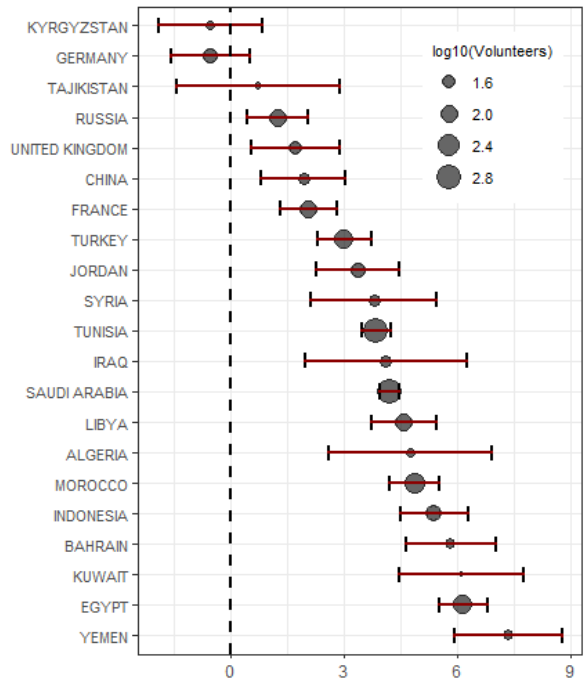

(a) Mean years education $+15 \mathrm{yrs}$.

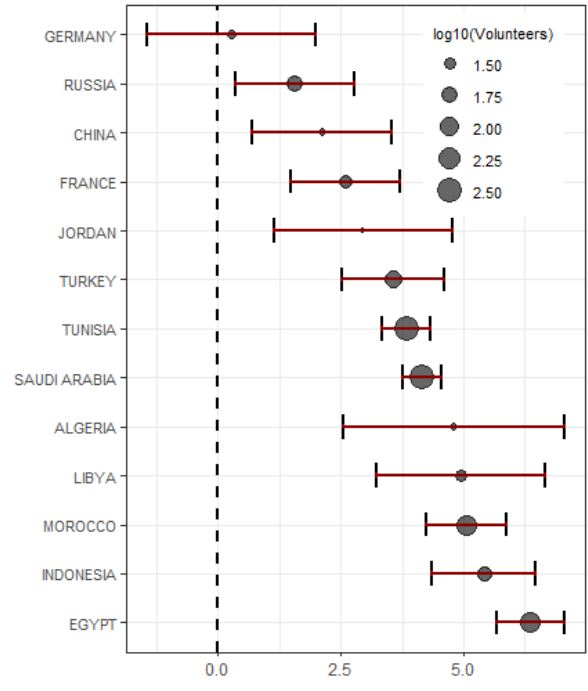

(b) Mean years of education $+25 \mathrm{yrs}$.

Figure 8: Sensitivity analysis for the mean years of education for Islamic State fighters against their home countries conditioned on age. Islamic State fighters form most states have higher mean years of education conditioned on age. All states were included in the experiment if there were 20 or more Islamic State recruits within that age range from a state. The confidence intervals are adjusted for multiple comparisons, so the experimentwise error rate is 0.05 .

\section{Education}

Fig 8 displays the confidence intervals for the one-sample $t$-tests for the mean years of education for Islamic State combatants 15 years and older and 25 years and older compared to males in the same age group from their home countries. For the first experiment, we removed all Islamic State combatants who were younger than 15 and estimated the difference in mean years. We find that Islamic State foreign fighters who are 15 years and older from all states have higher mean years of education compared to their respective home countries; except for Germany, Kyrgyzstan, and Tajikistan, which have confidence intervals overlapping zero. Similarly, when the Islamic State data is subset so that it only includes volunteers that are 25 years and older and compared to the mean years of education for their home countries, all states have higher mean years of education except for Germany, which has a confidence interval overlapping zero. 


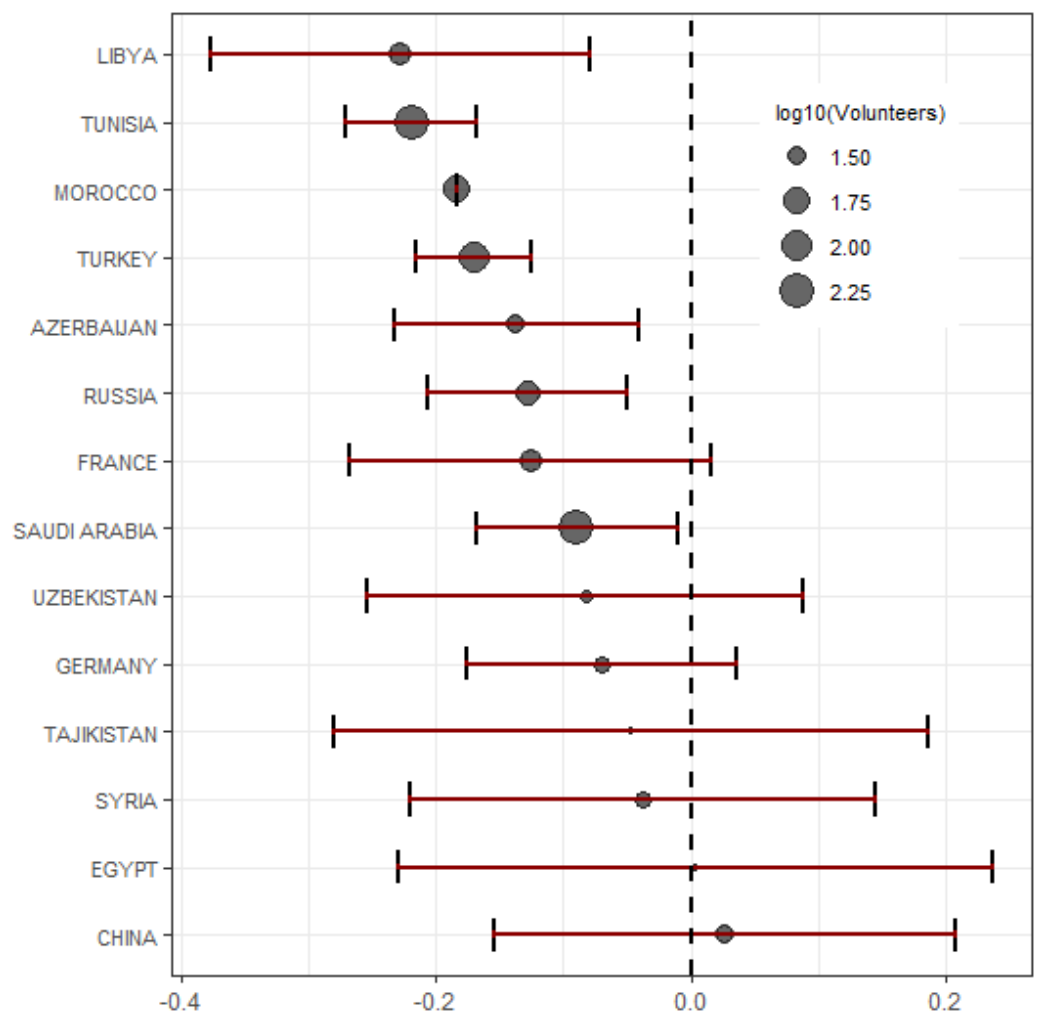

Figure 9: Sensitivity analysis for the proportion of Islamic State fighters unemployed against their home countries conditioned on age. All states have a confidence interval below or overlapping zero, which suggests that the proportion of Islamic State volunteers is lower than the male populations in their home countries conditioned on age. All states were included in the experiment if there were 20 or more Islamic State recruits within that age range from a state. The confidence intervals are adjusted for multiple comparisons, so the experimentwise error rate is 0.05 .

\section{Unemployment}

Fig 9 displays the confidence intervals for difference in proportion of unemployed Islamic State combatants between 15 and 25 years compared to males in that age range from their home countries. Seven out of the thirteen states have confidence intervals that are less than zero, which suggests the rate of unemployment for Islamic State fighters is lower than the male population between 15 and 24 in those states. 


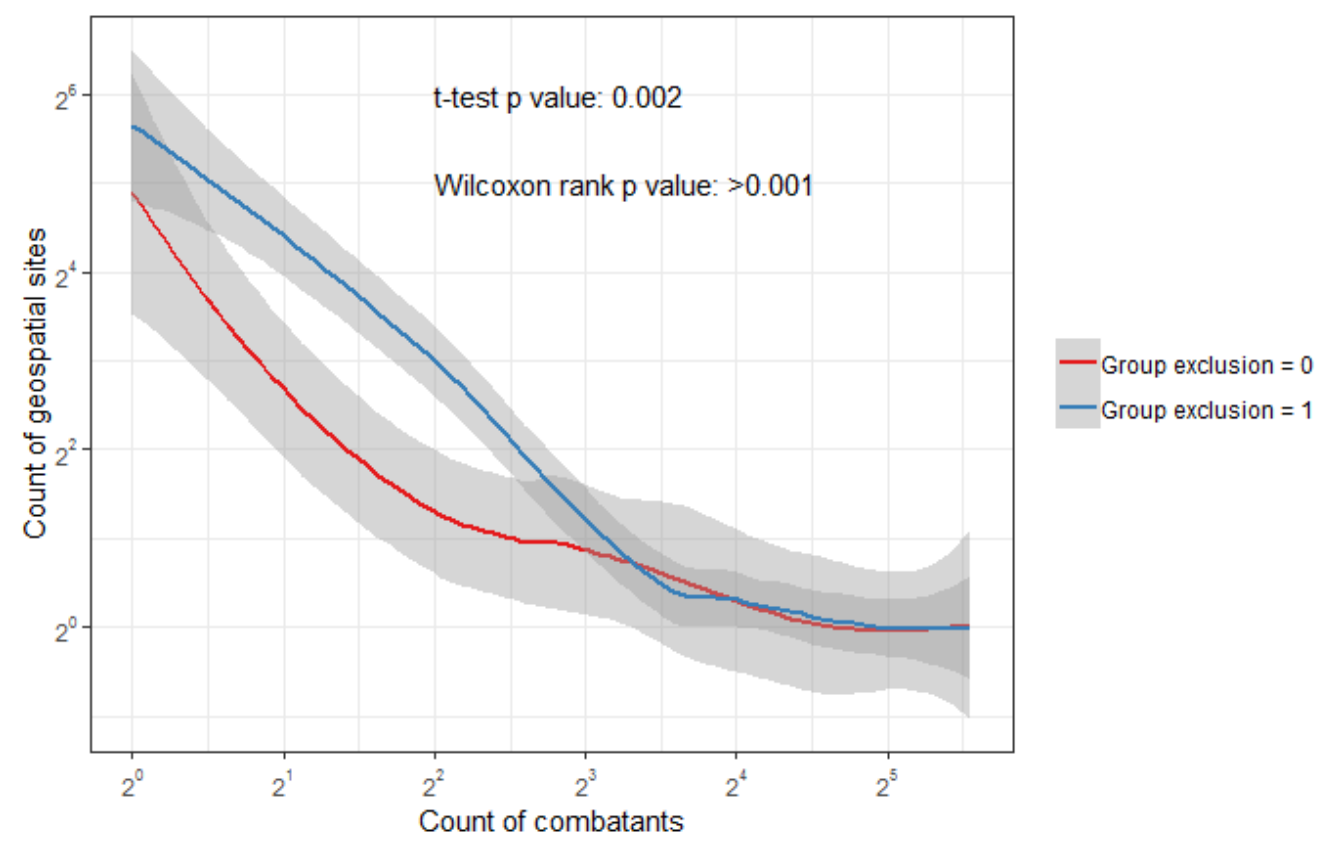

Figure 10: Sensitivity analysis for the difference in mean and mean rank counts of Islamic State fighters.

\section{Group exclusion}

Fig 10 displays the log-log plot for the count of Islamic State recruits from the sites for the matched geospatial data. We use two statistical tests to identify the treatment effect of group exclusion on combatant mobilization: (i) $t$-test for difference in mean number of recruits, and (ii) Wilcoxon rank sum test for a difference in the mean rank of recruits. In both models, we find that regions with excluded group have a higher mean and mean ranks of recruits at the 0.05 level.

\section{Discussion}

This analysis has important implications for United States and its allies' counterterrorism policies. Although the Islamic State is in the process of being pushed out of parts of Iraq and Syria, new organizations will likely replace it, and the region will continue to have rebel and terrorist problems. This paper provides a framework through which better counterterrorism 
policies can be crafted. Specifically, contrary to previous research, counterterrorism policies which seek to increase the economic opportunity of potential volunteers may be ineffective. Instead, counterterrorism policies should encourage states to integrate marginalized groups into their respective state's political systems and social communities.

\section{Conclusion}

This paper offers three contributions to research on terrorist recruitment and combatant mobilization. First, it offers a novel subnational analysis of Islamic State volunteers across countries. Second, it provides evidence that group rankings (i.e. group grievance) is the primary mechanism for Islamic State foreign fighter mobilization. Particularly, the political exclusion and social marginalization of populations produces greater group grievances, which increases the rate of combatant mobilization. And third, Islamic State combatants are not motivated by material incentives, as previous research has suggested. These findings are demonstrated through subnational analyses and individual comparisons for the years of education and proportion of unemployed Islamic State combatants against their home countries.

\section{Acknowledgments}

Thank you to professors Bear Braumoeller, Skyler Cranmer, Brad Holland, and Ore Koren for their comments on paper drafts. The research was supported by The Ohio State University Mershon Center. 


\section{References}

[1] Boutin B, Chauzal G, Dorsey J, Jegerings M, Paulussen C, Pohl J, et al. The Foreign Fighters Phenomenon in the European Union. ICCT Research Paper. 2016; p. 3-4.

[2] Didier B, Guild E. The EU Counter-Terrorism Policy Responses to the Attacks in Paris. Towards an EU Security and Liberty Agenda. Brussel: CEPS; 2015.

[3] Weinstein JM. Resources and the information problem in rebel recruitment. Journal of Conflict Resolution. 2005;49(4):598-624.

[4] Fearon JD, Laitin DD. Ethnicity, insurgency, and civil war. American Political Science Review. 2003;97(1):75-90.

[5] Salehyan I. Transnational rebels: Neighboring states as sanctuary for rebel groups. World Politics. 2007;59(2):217-242.

[6] Chuluv M. Islamic State document leak could offer up vignettes but not key secrets; 2016. The Gaurdian. Available from: https://www.theguardian.com/world/2016/ mar/10/isis-document-leak-could-offer-up-vignettes-but-not-key-secrets.

[7] MacAskill E. ISIS document leak reportedly reveals identities of 22,000 recruits; 2016. The Gaurdian. Available from: https://www.theguardian.com/world/2016/mar/09/ isis-document-leak-reportedly-reveals-identities-syria-22000-fighters.

[8] Johnston PB, Shapiro JN, Shatz HJ, Bahney B, Jung DF, Ryan PK, et al. Foundations of the Islamic State: management, money, and terror in Iraq, 2005-2010. Rand Corporation; 2016.

[9] Abdel-Jelil M, Bhatia K, Brockmeyer A, Do QT, Joubert C. Unemployment and violent extremism: Evidence from Daesh foreign recruits. World Bank: Policy Research Working Paper. 2015;13. 
[10] Sterman D. The Islamic State's veterans: Contrasting the cohorts with jihadi experience in Libya and Afghanistan. West Point: Combating Terrorism Center; June 2018.

[11] bin Khaled Al-Saud A. Saudi foreign fighters: Analysis of leaked Islamic State entry documents. King's College London: King Faisal Center for Research and Islamic Studies; 2019.

[12] National Consortium for the Study of Terrorism and Responses to Terrorism (START). Global Terrorism Database [Data file] Retrieved from https://wwwstartumdedu/gtd. $2018 ;.$

[13] Ross ML. What do we know about natural resources and civil war? Journal of Peace Research. 2004;41(3):337-356.

[14] Collier P, Hoeffler A. On the incidence of civil war in Africa. Journal of Conflict Resolution. 2002;46(1):13-28.

[15] Collier P, Hoeffler A. Greed and grievance in civil war. Oxford Economic Papers. 2004;56(4):563-595.

[16] Blattman C, Miguel E. Civil war. Journal of Economic literature. 2010;48(1):3-57.

[17] Koren O, Sarbahi AK. State Capacity, insurgency, and civil war: A disaggregated analysis. International Studies Quarterly. 2018;62(2):274-288.

[18] Vreeland JR. The effect of political regime on civil war: Unpacking anocracy. Journal of Conflict Resolution. 2008;52(3):401-425.

[19] Horowitz DL. Ethnic groups in conflict, updated edition with a new preface. University of California Press; 2001.

[20] Berrebi C. Evidence about the link between education, poverty and terrorism among Palestinians. Peace Economics, Peace Science and Public Policy. 2007;13(1). 
[21] Bergen P, Pandey S. The madrassa scapegoat. Washington Quarterly. 2006;29(2):115125.

[22] Lee A. Who becomes a terrorist? Poverty, education, and the origins of political violence. World Politics. 2011;63(2):203-245.

[23] Noricks DM. The root causes of terrorism. Social Science for Counterterrorism. $2009 ; 74(06-\mathrm{C}): 11$.

[24] Azam JP. Why suicide-terrorists get educated, and what to do about it. Public Choice. 2012;153(3-4):357-373.

[25] Holland M. Chechnya's internally displaced and the role of Russia's non-governmental organizations. Journal of Refugee Studies. 2004;17(3):334-346.

[26] Bou Nassif H. 'Second-Class': The Grievances of Sunni officers in the Syrian armed forces. Journal of Strategic Studies. 2015;38(5):626-649.

[27] Haddad F. Sectarian relations and Sunni identity in post-civil war Iraq. Sectarian Politics in the Persian gulf. 2014; p. 67-115.

[28] Wu X, Song X. Ethnic stratification amid China's economic transition: Evidence from the Xinjiang Uyghur autonomous region. Social Science Research. 2014;44:158-172.

[29] Najjar F. Iraq's second army: Who are they, what do they want?; 2017. Al Jazeera. Available from: https://www.aljazeera.com/news/2017/10/ iraq-army-171031063012795.html.

[30] Hegghammer T, Zelin AY. How Syria's civil war became a holy crusade; 2013. Foreign Affairs. Available from: https://www.google.com/search?q=How+Syria\%27s+civil+ war+became+a+holy+crusade\&rlz=1C1CHBF_enUS705US705\&oq=How+Syria\%27s+ civil+war+became+a+holy+crusade\&aqs=chrome. .69i57j69i65j69i60.794j0j4\& sourceid=chrome\&ie=UTF -8 . 
[31] Middle East Quarterly. King Abdullah II: Iraq is the battlegroundthe West against Iran, Vol; 2005. Washington Institute. Available from: https://www. washingtoninstitute.org/policy-analysis/view/ king-abdullah-ii-iraq-is-the-battlegroundthe-west-against-iran.

[32] Spier TE. Extremist propaganda and Qur'anic scripture: A 'radical'corpus-based study of the Dabiq. Discourse \& Society. 2018;29(5):553-567.

[33] Francis D. Islamic State Revenues Down 80 Percent from 2015; 2017. Foreign Policy. Available from: https://foreignpolicy.com/2017/06/29/ islamic-state-revenues-down-80-percent-from-2015/.

[34] Zhang Q, Seto KC. Mapping urbanization dynamics at regional and global scales using multi-temporal DMSP/OLS nighttime light data. Remote Sensing of Environment. 2011;115(9):2320-2329.

[35] Chen X, Nordhaus WD. Using luminosity data as a proxy for economic statistics. Proceedings of the National Academy of Sciences. March 2018;108(21):8589-8594.

[36] Doll CN, Muller JP, Morley JG. Mapping regional economic activity from night-time light satellite imagery. Ecological Economics. 2006;57(1):75-92.

[37] United Nations Development Program. Human development report 2016. 2017;

[38] Kaufmann D, Kraay A, Mastruzzi M. The worldwide governance indicators: methodology and analytical issues. Hague Journal on the Rule of Law. 2011;3(2):220-246.

[39] Tollefsen AF, Strand H, Buhaug H. PRIO-GRID: A unified spatial data structure. Journal of Peace Research. 2012;49(2):363-374.

[40] Kaufmann D, Aarat K. The Worldwide Governance Indicators Project. 2019;.

[41] Barro RJ, Lee JW. A new data set of educational attainment in the world, 1950-2010. Journal of Development Economics. 2013;104:184-198. 
[42] Marshall MG, Jaggers K, Gurr TR. Polity IV project, political regime characteristics and transitions, 1800-2017; 2018. Center for Systemic Peace. Available from: https: //www.systemicpeace.org/polity/polity4x.htm.

[43] Lindberg JE. Running on Faith? A Quantitative Analysis of the Effect of Religious Cleavages on the Intensity and Duration of Internal Conflicts. Peace Research Institute of Oslo. 2008; 